\title{
An Epidemiologic and Economic Study of Respiratory Diseases in Two Conventional Danish Swine Herds. I: Prevalence of Respiratory Lesions at Slaughter and Their Effects on Growth
}

\author{
By L. G. Paisley, L. Vraa-Andersen, L. Dybkjaer, K. Mфller, G. Chrıstensen, J. Mousing and J. F. Agger
}

Department of Animal Science and Anımal Health, Division of Ethology and Health, Royal Veterinary and Agricultural University, Frederiksberg, and Veterinary Divisıon, The Federation of Danısh Pig Producers and Slaughterhouses, Kjellerup and Copenhagen, Denmark.

\begin{abstract}
Paisley, L.G., L. Vraa-Andersen, L. Dybkjær, K. Møller, G. Christensen, J. Mousing and J.F. Agger. An epidemiologic and economic study of respiratory diseases in two conventional Danish swine herds. I: Prevalence of respiratory lesions at slaughter and their effects on growth. Acta vet. scand. 1993, 34, 319-329. - A total of 578 slaughter pigs from 2 Danish conventional farrow-to-finish operations (Herds A and B) were followed from an age of 14 days to slaughter. Pigs were weighed at 3 weeks intervals and at slaughter and an extended post mortem examination of the plucks was done. Comparison of growth rates in pigs with and without specific types of lesions by the t-test and those with multiple lesions with regression models demonstrated that Mycoplasma-like pneumonia, complicated pneumonia, anterio-ventral pleurits, fissures and atrophic rhinitis significantly reduced mean daily gain and increased the tıme required to reach slaughter weight. The total impact of the lesions in Herd A was an estimated reduction in mean daily gain of 27 grams and a 2 day increase in the interval from 14 days of age until slaughter (MDG14). Decreases in MDG14 in Herd B were more substantial, 98 grams and 16.7 days. Reductions in mean daily gains during the interval from the fourth weighing until slaughter were 31 grams in Herd A and 137 grams in Herd B. Chronic dorso-caudal and paretal pleuritis, without other lesions present, had no significant adverse effects on growth rates in either herd. Interactions between lesions did not significantly alter the estimates. The $\mathbf{R}^{2}$ values obtained for the regression models showed that the presence, absence or extent of lesions at slaughter explained only $13-27 \%$ of the variations in growth rates in the 2 herds.
\end{abstract}

pneumonia; pleuritis; atrophic rhinitis; growth rate.

\section{Introduction}

Respiratory diseases cause losses to the swine industry via mortalities, decreased growth rates, reduced feed conversion efficiency, reduced carcass quality and condemnations, and increased expenditures for therapy and prevention (Lindqvist 1974, Aalund et al. 1976, Christensen 1982, Friendship et al. 1984, Pointon et al. 1985, Ross 1984, Rassmussen 1984, Straw et al. 1983, Straw et al. 1985, Derosiers \& Moore 1986).
Meat inspection data and special veterinary examinations at slaughter have provided much information regarding the types and prevalences of respiratory lesions in slaughter swine (Aalund et al. 1976, Boessen et al. 1988, Flesja \& Solberg 1981, Saunders et al. 1981, Sanker et al. 1982, Rassmussen 1984, Sanker \& Staugaard 1988, Christensen 1986, Mousing 1988, Mousing et al. 1989, Noyes et al. 1990, Scheit et al. 1990, 
Straw et al. 1983, Straw et al. 1985, Willeberg et al. 1982). Danish national statistics show that pneumonia and pleuritis account for more than 2/3 of the recorded lesions at slaughter (Aalund et al. 1976, Willeberg et al. 1984/85).

The impact of respiratory lesions on growth and feed conversion efficiency is not easy to clarify. Many studies have reported negative effects of pneumonia, chronic pleuritis and atrophic rhinitis on parameters such as mean daily gain, feed efficiency and days required to reach slaughter weight. However, the results of existing studies are not consistent. Based on a review and analysis of 27 studies of swine pneumonia, Straw et al. (1989), concluded that, on the average, each $10 \%$ of lung affected by Mycoplasma or Actinobacillus pneumonia reduced mean daily gains by 37.4 grams.

Some authors have associated atrophic rhinitis with reduced growth rates and/or feed efficiency (Baalsrud 1987, Cowart et al. 1990, Pedersen \& Barfod 1981, Bäckstrom et al . 1985) while others have reported no negative effects (Straw et al. 1983, Straw et al. 1985, Love et al. 1985). The effects of atrophic rhinitis were measurable in some herds but not in others (Wilson et.al. 1986).

The objectives of this study were to compare the growth rates of pigs with and without respiratory lesions and variable grades of atrophic rhinitis detected at slaughter and further to determine the impact of interactions between the lesions, by examining pigs from 2 conventional herds with high prevalences of respiratory disease.

\section{Materials and methods}

The sample consisted of 654 pigs from 2 farrowto-finish operations located on the island of Sealand, Denmark. Farm A maintained 800-1000 sows and marketed about 20,000 pigs each year. Farm B had approximately 140 sows and produced about 3,000 slaughter pigs per year. The pigs were weaned at approximately 21 days of age on Farm A and at 25 days on Farm B. The range in weaning ages was from 15 to 30 days on both farms. The males were castrated during the first week on Farm A, while the males were not castrated at Farm B. At weaning the pigs were housed in temperature controlled rooms, on solid feed, for 3 to 6 weeks. They were then moved to unheated growing/fattening barns with restricted wet feeding. At Farm A, litters were mixed at weaning but during the rest of the growing period the houses were managed on an "all in - all out" system. At Farm B, there was continual mixing of different aged pigs throughout the post-weaning period.

The farms were selected on the basis of 3 criteria: 1 . A prevalence of at least $25 \%$ chronic pleuritis in their slaughter swine; 2 . Computerized production monitoring and 3. Owners willingness to participate in the study. Serological screening of 20 animals from each herd confirmed the presence of Actinobacillus pleuropneumoniae, serotype 2, Haemophilus parasuis and Influenza suis (H1N1). Infections with these agents have been identified as risk factors in the development of chronic pleuritis (Mousing et al. 1989).

Five groups of 60-65 piglets on Farm A and 6 groups of about 50-55 piglets on Farm B were selected for inclusion in the study. The target age for inclusion was $14 \pm 6$ days. If a litter was selected all piglets were included except piglets that had been fostered into the litter. Piglets selected for breeding were excluded because slaughter records could not be obtained. New groups from each farm were included in the study at 4 week intervals during the period September, 1989 until January, 1990.

When selected, the piglets were individually identified with tattoos in both ears, weighed and bled. Individual records containing information such as date of birth, identification of sow and boar, breed, sow's parity number, number 
born, number of stillborn, number weaned, weaning date, dates of illnesses and treatments, dates of prophylactic procedures, sex, castration dates if applicable, dates of movements to the growing or finishing barns, weights and miscellaneous comments were maintained throughout the study period, from September, 1989 through July, 1990. At 3 week intervals, until they were 20 weeks old, the pigs were bled and weighed. Thus, all surviving pigs were weighed and bled at least 7 times at the farms. The pigs were slaughtered when they had reached a live weight of approximately $95 \mathrm{~kg}$. However, at the end of the study period all remaining pigs were slaughtered regardless of body weight.

All pigs were slaughtered at the same slaughterhouse. A blood sample was collected at exsanguination. During the routine meat inspection procedures carcasses with obvious parietal pleuritic lesions were identified and tagged by the inspectors. These lesions were classified as chronic parietal pleuritis (CPPL). Besides the routine inspection an extensive visual and digital examination of each pluck was conducted by the same veterinarian (Christensen 1991). The type, extent and location of all lesions observed were recorded on schematic diagrams of the lungs, thoracic cavity and heart (Fig. 1). The percentage of each lobe and the total percentage of the lungs affected by pneumonic, pleuritic or other lesions were estimated from these diagrams. The lesions were qualitatively classified by their gross appearances according to the following definitions:

Mycoplasma-like pneumonia (MPLP): Purple or grayish purple, sunken and well demarcated meaty areas usually confined to the anterio-ventral lobes.

Complicated pneumonia (COMP): Bronchopneumonia with purulent exudate in the bronchi, fibrosis or abscessation.

Acute pleuropneumonia (PLPN-A): Firm, irregularly shaped areas of hyperemia, hem- orrhages, grayish foci of necrosis and interlobular edema. The pleura was covered by fibrinous exudate. Usually confined to the dorso-caudal lobes.

Subacute-chronic pleuropneumonia (PLPN-C): Well demarcated areas of necrosis or abscessation surrounded by fibrosis. Chronic fibrotic and adhesive pleuritis was often associated with these lesions. Usually confined to the dorso-caudal lobes.

Chronic pleuritis of the dorso-caudal lobes (CPDC): Chronic pleuritis confined to the dorso-caudal lobes, often associated with adhesion to the parietal pleura.

Chronic pleuritis of the anterio-ventral lobes (CPAV): Pleuritis of the anterior ventral pleural surfaces. Often with adhesions to the parietal pleura and often associated with CPDC.

Fissures (FISS): Interlobular scarring or bands of fibrosis located in the anterioventral lobes.

Pericarditis (PERC): Fibrosis and adhesions of the pericardium, often involving the myocardium and adjacent pleura. Histo-pathological examinations of the lesions were not done.

Using the method of Collins et. al. (1989), a turbinate perimeter ratio for each nostril was calculated. From the mean turbinate perimeter ratio (MEANTPR) an atrophic rhinitis score (AR), 0-3 was assigned (Paisley 1991).

The live weight at slaughter was estimated from the carcass weight by specific formulas for gilts, barrows or boars (Kjeldsen et al. 1990). The mean daily gains from the first weighing until slaughter (MDG14) and from approximately 25 kgs. body weight (fourth weighing) until slaughter (MDG25) were calculated. Age at slaughter (SLAGE) was the number of days between the date of birth and the date of slaughter.

\section{Statistical analysis}

The slaughter age and mean daily gains in the 
2 herds were compared by the t-test. The data were stratified by herd and the same performance characteristics were compared in pigs with and without each specific type of lesion.

The CPPL and PERC were coded as present " 1 ", or absent " 0 ". FISS was classified as mild, moderate or severe. For the other lung lesions the percentage of the total lung surface or parenchyma affected was used as continuous variables. Atrophic rhinitis scores were assigned, based on the mean turbinate perimeter ratios (Paisley 1991). A MEANTPR $<0.97$ was scored as $\mathrm{AR}=3 ; 0.97<\mathrm{MEANTPR}<1.25$ was scored as $\mathrm{AR}=2 ; 1.26<\mathrm{MEANTPR}<1.54$ as $\mathrm{AR}=1$ and MEANTPR $>1.54$ as $\mathrm{AR}=0$.

Mean lesion scores based on the percentage of lung affected were calculated for each herd and for affected animals within each herd. The numbers of pigs with multiple lesions were also calculated. Interaction scores for the most common concurrent lesions were calculated by multiplying the individual lesion scores.

Mean daily gains from the first weighing until slaughter (MDG14), from the fourth weighing until slaughter (MDG25) and age at slaughter (SLAGE) were regressed against the lesions by backward, stepwise, multiple linear regression (SAS Institute Inc. 1985).

To remain in the model the coefficient of an independent variable needed a $\mathrm{P}$-value $\leq 0.05$. The saturated model included up to third order interaction terms and was of the general form:

\section{$\mathrm{MDG}_{1}=\alpha_{0}+\beta_{1} \mathrm{~S}+\beta_{2} \mathrm{MPLP}+\beta_{3} \mathrm{COMP}+\beta_{4} \mathrm{FISS}+\beta_{5} \mathrm{CPDC}+\beta_{6} \mathrm{CPAV}+\beta_{7} \mathrm{CPPL}+\beta_{8} \mathrm{PERC}+$ $\beta_{9} \mathrm{AR}+\gamma_{1} \mathrm{MPLP} * \mathrm{COMP}+\delta_{1} \mathrm{MPLP} * \mathrm{COMP} * \mathrm{FISS} .$.}

Where $\mathrm{MDG}_{1}=$ Mean daily gain during interval "i";

$\mathrm{S} \quad=\operatorname{Sex}(0=$ female, $1=$ male $)$;

MPLP = Mycoplasma pneumonia (\% lung tissue affected);

COMP = Complicated pneumonia (\% lung tissue affected);

FISS $=$ Fissures $(1=$ mild, $2=$ moderate, $3=$ severe $)$;

CPDC = Dorso-caudal pleuritis (\% lung surface affected);

$\mathrm{CPAV}=$ Anterio-ventral pleuritis (\% lung surface affected;

CPPL = Parietal pleuritis $(0=$ absent, $1=$ present $)$;

PERC = Pericarditis $(0=$ absent, $1=$ present $)$;

AR = Atrophic rhinitis (scores 0,1,2,3);

MPLP*COMP = Interaction between Mycoplasma pneumonia and complicated pneumonia; MPLP*COMP*FISS = Interaction between Mycoplasma pneumonia, complicated pneumonia and fissures;

The intercepts of the regression equations were used as estimates of the herd mean daily gains when all lesions were equal to " 0 " i.e, the mean daily gain of the "non-diseased group". From these equations the impacts of the lesions on mean daily gains and slaughter age were estimated by subtracting the intercept from the Herd mean daily gain or mean slaughter age.

Standard microcomputer software (SAS Insti- tute Inc. 1985) was used to tabulate data and to perform statistical procedures.

\section{Results}

Slaughter data was obtained for 593 of the 654 pigs that were included in the study. Nine pigs from Farm A and 6 from Farm B were lost to follow-up or had incomplete data and were excluded from the analyses. The results are 
Table 1. Descriptive statistics for Herds A and B.

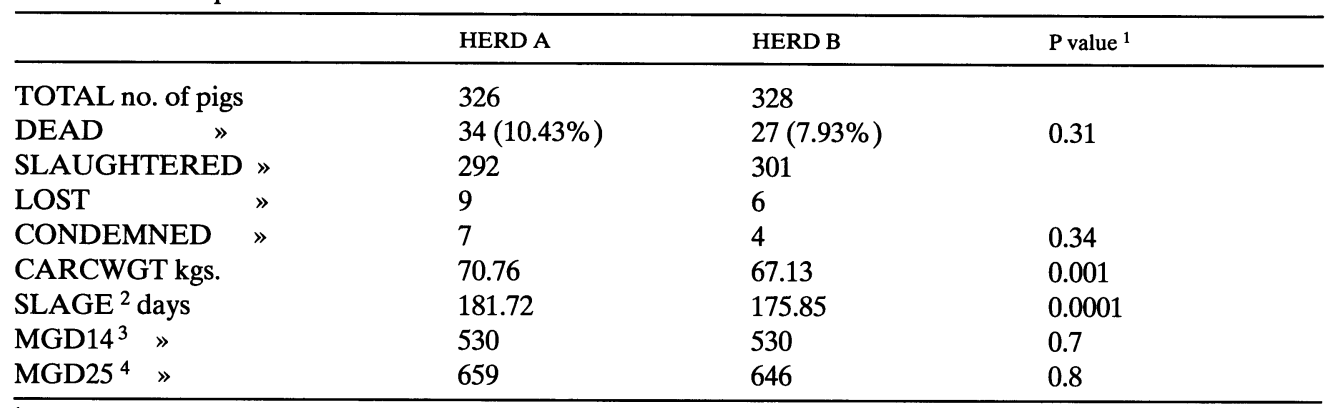

${ }^{1}$ Differences were tested with the t-test

2 SLAGE = Aage at slaughter (days)

${ }^{3}$ MDG14 = Mean dally gain from 14 days of age, untıl slaughter.

${ }^{4}$ MDG25 = Main daily gain from fourth weighing until slaughter.

based on 283 pigs from Herd A and 295 from Herd B with complete data.

Table 1 presents some descriptive statistics for the 2 cohorts. The mean daily gains from 14 days until slaughter and from 25 kgs. until slaughter were not significantly different between the 2 herds but the mean slaughter age and slaughter weight of Herd A pigs were significantly higher than in Herd $B$.

Both herds had high prevalences of thoracic lesions. Only $7.5 \%$ and $1.3 \%$ of the pigs in Herds A and B, respectively, lacked lesions. Herd B had significantly more pigs with most types of lesions than Herd A (Table 2). The mean percentages of lung affected by the various lesions were higher in Herd B but there were no significant differences in percentages of lung involved in the affected pigs from the 2 herds when individual lesions were compared. The mean interaction scores for multiple lesions were significantly higher in Herd B (Table 3).

When the daily gains and slaughter age of pigs with and without each specific lesion were compared by the t-test, all lesions, except dorso-caudal pleuritis in pigs from Herd $\mathrm{A}$, were associated with lower mean daily gains or an extended growing period . However, in Herd A, most of the differences were not statistically significant (Table 4). In Herd A pigs, only Mycoplasma-
Table 2. Results of the extensive plucks examinations. The table shows the percentage of pigs affected with each type of lesion.

\begin{tabular}{lrrl}
\hline LESION ${ }^{1}$ & $\begin{array}{r}\text { HERD A } \\
\text { \% of pigs }\end{array}$ & $\begin{array}{r}\text { HERD B } \\
\text { \% of pigs }\end{array}$ & P value $^{2}$ \\
\hline MPLP & 62.7 & 78.7 & 0.0001 \\
COMP & 5.8 & 9.6 & 0.08 \\
FISS-3 & 1.3 & 6.3 & 0.002 \\
FISS-2 & 13.6 & 27.5 & 0.000 \\
FISS-1 & 20.2 & 15.9 & 0.001 \\
PLPN-A & 2.4 & 0.3 & 0.01 \\
PLPN-C & 5.8 & 12.3 & 0.01 \\
CPDC & 52.4 & 62.7 & 0.007 \\
CPAV & 36.6 & 50.8 & 0.0001 \\
PERC & 4.8 & 11.6 & 0.002 \\
AR-3 & 4.3 & 13.2 & 0.000 \\
AR-2 & 25.4 & 33.9 & 0.023 \\
AR-1 & 20.2 & 22.4 & 0.50 \\
AR-0 & 50.0 & 27.8 & 0.0001 \\
CPPL & 44.5 & 54.2 & 0.02 \\
MPLP*CPAV & 24.0 & 38.0 & 0.0001 \\
MPLP*CPDC & 30.7 & 48.8 & 0.0001 \\
CPDC*CPAV & 20.5 & 32.9 & 0.001 \\
MPLP*CPAV*CPDC & 13.4 & 24.6 & 0.001 \\
NONE & 7.5 & 1.3 & 0.02 \\
\hline 1.MPLP & &
\end{tabular}

1. MPLP = Mycoplasma pneumonı; COMP = complicated pneumonia; FISS-3 = severe interlobular scarring and fibroSIS; FISS-2 = moderate interlobular scarring and fibrosis; DISS=1 $=$ mild interlobular scarring and fibrosis, PLPN-A = acutepleuropneumonia; $\mathrm{PLPN}-\mathrm{C}=$ subacute/chronıc pleuropneumonia; $\mathrm{CPDC}=$ dorsocaudal pleurits, $\mathrm{CPAV}=$ anterioventral pleuritıs; $\mathrm{PERC}=$ pericarditıs, $\mathrm{AR}-3=$ severe atrophic rhinitıs; AR-2 = moderate atrophic rhinitı; AR-1 = mild atrophic rhinits; $\mathrm{AR}-0=$ no atrophic rhinitis; $\mathrm{CPPL}=$ panetal pleuntis; NONE $=$ no recorded lesions.

2 The significance of the differences were tested by the Chi-square test 
Table 3. Mean lesion scores expressed as the percentage of lung affected.

\begin{tabular}{lllllc}
\hline & \multicolumn{2}{l}{ TOTAL HERD } & & \multicolumn{2}{c}{ AFFECTED PIGS } \\
\cline { 2 - 3 } \cline { 5 - 6 } LESION $^{1}$ & HERD A & HERD B & & HERD A & HERD B \\
\hline MPLP & 3.93 & $5.83^{*}$ & & 6.33 & $7.46 \mathrm{~ns}$ \\
COMP & 0.23 & $0.67^{*}$ & & 4.00 & $7.03 \mathrm{~ns}$ \\
CPAV & 1.93 & $2.79^{*}$ & & 5.32 & $5.53 \mathrm{~ns}$ \\
CPDC & 3.77 & $5.19^{*}$ & & 7.21 & $8.23 \mathrm{~ns}$ \\
MULTIPLE LESIONS & & & \\
MPLP*COMP & & & 0.67 & $4.90 * *$ \\
MPLP*CPAV & & & 7.92 & $14.33 *$ \\
MPLP*CPDC & & & 14.22 & $30.24 * *$ \\
CPAV*CPDC & & & 16.32 & $30.57 \mathrm{~ns}$ \\
MPLP*CPAV*CPDC & & 52.39 & $85.40 \mathrm{~ns}$ \\
COMP*CPAV & & 0.46 & $5.25 *$ \\
COMP*CPDC & & 0.80 & $4.23 *$ \\
\hline
\end{tabular}

$*=0.05>\mathrm{p}>0.01 ; \quad * *=0.01>\mathrm{p}>0.001 ; \mathrm{ns}=\mathrm{p}>0.05$

${ }^{1}$ For abbreveations see Table 2.

like pneumonia and severe atrophic rhinitis $(A R=3)$ were associated with significantly lower mean daily gains from the first weighing until slaughter (MDG14) and only Mycoplasma-like pneumonia significantly affected gains during the interval from the fourth weighing (MDG25) until slaughter. Only severe atrophic rhinitis (AR3) significantly increased the growing period (SLAGE).

In Herd B, all lesions except fissures were asso- ciated with significantly lower MDG14. Dorsocaudal pleuritis and fissures were not associated with significantly lower MDG25. Mycoplasma pneumonia, complicated pneumonia and dorsocaudal pleuritis did not significantly affect SLAGE (Table 4).

Multiplication of the differences in mean daily gains of pigs with and without each lesion by the percentage of pigs with each lesion was done to estimate the amount each lesion changed the mean daily gain of the herd. Totaling the contributions of each lesion provided an estimate of the additive effect of all the lesions if no multiplicative effects of lesions was assumed. Using this procedure the estimated reductions in MDG14 were 25.3 grams (4.78\%) and 63.0 grams $(11.8 \%)$ in Herds A and B, respectively. Estimated reductions in MDG25 were 33.0 grams $(5.0 \%)$ and 99.1 grams $(18.75 \%)$, respectively.

When modeling the effects of the lesions on mean daily gains by backward, stepwise multiple regression, initially, it appeared that several interactions between lesions were important. However, when the main effects of the lesions that interacted were forced into the models none of the interactions were significant.

In Herd A, mean daily gain during the interval

Table 4. Differences in rates of gain (gain/day) and age (days) at slaughter in pigs with each type of lesion at slaughter compared to pigs without lesions.

\begin{tabular}{|c|c|c|c|c|c|c|}
\hline \multirow[b]{2}{*}{ LESION } & \multicolumn{3}{|c|}{ HERD A } & \multicolumn{3}{|c|}{ HERD B } \\
\hline & MDG14 & MDG25 & SLAGE & MDG14 & MDG25 & SLAGE \\
\hline MPLP & $-18^{* *}$ & $-26 * *$ & +1.56 & $-14^{*}$ & $-26^{*}$ & +1.97 \\
\hline COMP & -15 & -14 & +3.36 & $-45^{*}$ & $-81 * * *$ & +5.1 \\
\hline CPDC & +8 & +5 & -0.81 & $-17^{*}$ & -14 & +0.92 \\
\hline CPAV & -14 & -19 & +2.93 & $-30 * *$ & $-42 * *$ & $+6.85^{* *}$ \\
\hline PERC & -18 & -18 & +9.11 & $-64 * *$ & $-80 * * *$ & $+11.2 * *$ \\
\hline FISS & -27 & -27 & +7.66 & -14 & -16 & $+4.17 *$ \\
\hline AR3 & $-34 * *$ & -39 & $+6.87 *$ & $-60 * * *$ & $-94 * * *$ & $+10.5^{* *}$ \\
\hline CPPL & -14 & -12 & +2.69 & $-21 * *$ & $-28^{*}$ & $+4.73 * *$ \\
\hline
\end{tabular}

Differences were tested for significance with the t-test. $\quad *=0.05<\mathrm{p}<0.01 ; \quad * *=0.01<\mathrm{p}<0.001$; $* * *=\mathrm{p}<0.001$.

For abbreviations see Table 2 . 
Table 5. The results (p-values of backward stepwise regression of mean daily gains and slaughter age against the lesions in Herd A.

\begin{tabular}{llll}
\hline Variable & MDG14 & MDG25 & Slaughter age \\
\hline Intercept & 0.0001 & 0.0001 & 0.0001 \\
MPLP \% & 0.006 & 0.0001 & 0.0527 \\
CPDC \% & 0.0122 & 0.0279 & 0.0152 \\
CPAV \% & 0.0007 & 0.0052 & 0.0003 \\
FISS-2 & 0.0238 & & 0.0310 \\
AR=3 & 0.0044 & 0.0115 & \\
AR=2 & 0.0033 & 0.0061 & \\
AR=1 & 0.0388 & 0.0080 & \\
COMP \% & & 0.0493 \\
MDG14-INTERCEPT $=530-557=-27 \mathrm{~g}(4.8 \%)$ \\
MDG25 - INTERCEPT $=659-690=-31 \mathrm{~g}(4.5 \%)$ \\
Mean SLAGE - Intercept $=181.1-179.7=$ \\
2.0 days $(1.1 \%)$
\end{tabular}

${ }^{1}$ Mean SLAGE = Mean slaughter age.

For abbreviations see Table 2.

from the first weighing until slaughter (MDG14) was reduced by an estimated 27 grams $(4.8 \%)$ by the combined effects of all the lesions. Dorso-caudal pleuritis was associated with increased mean daily gains. Mean daily gain during the interval from the fourth weighing (ca. $25 \mathrm{~kg}$. body weight) until slaughter (MDG25) was reduced by an estimated 31 grams $(4.5 \%)$ by the combined effects of the lesions. Complicated pneumonia was associated with significantly decreased MDG25 but not MDG14. The results of the regression models were very similar to the estimates obtained from the t-test. The growth and fattening period (SLAGE) was extended an estimated 2 days by the combined effect of the lesions. Mycoplasma-like pneumonia, anterio-ventral pleuritis and fissure- 2 added time to the growth period while dorso-caudal pleuritis was associated with a nonsignificant shorter growth period. The final regression models for Herd $\mathrm{A}$ are shown in Table 5.

In Herd B, mean daily gains during the interval from the first weighing until slaughter were reduced by an estimated 98 grams $(15.4 \%)$ by
Table 6. The results (p-values of backward stepwise regression of mean daily gains and slaughter age against the lesions in Herd $\mathrm{B}$.

\begin{tabular}{llcl}
\hline Variable & MDG14 & MDG25 & Slaughter age \\
\hline Intercept & 0.0001 & 0.0001 & 0.0001 \\
MPLP \% & 0.0001 & 0.0001 & \\
CPAV \% & 0.0006 & & 0.0002 \\
FISS-2 & 0.0481 & & 0.0345 \\
FISS-3 & 0.0402 & & \\
AR=3 & 0.0001 & 0.0001 & 0.0004 \\
AR=2 & 0.0087 & 0.0147 & 0.0261 \\
AR=1 & 0.0153 & 0.0118 & 0.0340 \\
COMP \% & 0.0059 & 0.0001 & \\
MDG14-INTERCEPT $=530-628=-98 \mathrm{~g}(15.4 \%)$ \\
MDG25 - INTERCEPT $=646-783=-137 \mathrm{~g}(17.5 \%)$ \\
Mean SLAGE - Intercept $=175.6-158.9=$ \\
16.7 days (10.5\%)
\end{tabular}

For abbreviations see Tables 2 and 5.

the combined effects of all the lesions. Severe fissures (FISS-3) $(\mathrm{p}=0.04)$ were associated with increased mean daily gains. The estimate obtained from the t-test results was 63 grams. Mean daily gain during the interval from the fourth weighing (ca. $25 \mathrm{~kg}$. body weight) until slaughter was reduced by an estimated 137 grams $(17.5 \%)$ by the combined effects of Mycoplasma-like pneumonia, complicated pneumonia and atrophic rhinitis. This compares with an estimated 99.1 grams reduction based on t-test results.

The growth and fattening period was extended by an estimated 16.7 days (10.5\%) by the combined effects of fissures, anterio-ventral pleuritis and atrophic rhinitis. The final regression models for MDG14, MDG25 and SLAGE are shown in Table 6.

\section{Discussion}

Comparing the effects on growth rates of lesions detected at slaughter by the $t$-test has several flaws. First, categorization of the lesions as present or absent does not address the possibility that the effects are related to the degree of lung involvement. However, categorization of the 
degree of lung involvement as above or below the median score of affected pigs did not increase the significance of the observed differences (Paisley 1991). Second, comparing growth rates of pigs with and without a specific lesion does not take into account the effects that other lesions might have. This can lead to comparison of growth rates in groups of pigs with different diseases or combinations of diseases rather than comparing diseased and non-diseased groups. This might result in over- or under-estimation of the importance of some lesions. In this study most pigs had more than one type of lesion. Fifty-nine (20.8\%) Herd A pigs and 48 (16.3\%) Herd B pigs had Mycoplasma-like pneumonia as the only recorded lesion. Only 22 pigs from Herd A and 4 pigs from Herd $B$ had no thoracic lesion. In addition, based on the turbinate perimeter ratios, the majority of pigs had some degree of atrophic rhinitis. Atrophic rhinitis was shown to have a negative effect on growth in both herds. The estimated reductions in mean daily gains from 14 days until slaughter were 25.3 and 63.0 grams in Herds A and B, respectively, when the mean daily gains of pigs affected and non-affected by each type of lesion were compared.

The estimated reductions in mean daily gains from the first weighing, at about 14 days of age until slaughter, estimated by backward stepwise regression analyses were 27 and 98 grams in the respective herds. The estimated reduction in mean daily gain between the fourth weighing, at about 77 days of age and $25 \mathrm{kgs}$. body weight, were 31 and 137 grams in the 2 respective herds. These estimates are probably more realistic than those derived from comparison of growth rates in pigs with and without a single specific type of lesion because most of the pigs had multiple lesions.

Chronic pleuritis was of major interest in this study because it is thought to cause significant reductions in growth rates in swine. Christensen $(1982,1984)$ reported that pigs with chronic pleuritis took 7 or 12 days longer to reach slaughter than non-affected pigs. Chronic pleuritis is generally regarded to be evidence of an earlier Actinobacillus pleuropneumoniae infection (Nielsen \& Mandrup 1977, Christensen 1981, Friendship et al. 1984, Derosiers \& Moore 1986, Saunders et al. 1981, Mousing et al. 1989). In the present study chronic pleuritis was categorized by location: Dorso-caudal pleuritis, anterio-ventral pleuritis and parietal pleuritis. Pleuritis confined to the dorso-caudal lobes is primarily associated with Actinobacillus pleuropneumoniae infections. Anterio-ventral pleuritis is not commonly reported as a sequela to Actinobacillus pleuropneumoniae infections but is often associated with lesions such as pericarditis and complicated pneumonia. Parietal pleuritis was detected during the routine inspection and was usually associated with anterioventral or dorso-caudal pleuritis or both. When compared by the t-test, parietal pleuritis and dorso-caudal pleuritis appeared to be associated with decreased mean daily gains and increased age at slaughter. The differences were statistically significant only in Herd B. However, when the pigs with anterio-ventral pleuritis were excluded there were no differences in mean daily gains or slaughter ages in pigs with and without parietal pleuritis. The same was true for pigs with dorso-caudal pleuritis. Reductions in mean daily gains associated with parietal or dorso-caudal pleuritis appear to be due to the effects of anterio-ventral pleuritis or other concurrent diseases such as Mycoplasma pneumonia, complicated pneumonia, anterio-ventral pleuritis, pericarditis and atrophic rhinitis. These results were confirmed by stepwise backward multiple regression models. Mycoplasma pneumonia, complicated pneumonia, anterio-ventral pleuritis, pericarditis and atrophic rhinitis warrant more attention than Actinobacillus infections with regard to their effects on growth rates in these 2 herds. 
The impact of the diseases on the herd growth rates might have been underestimated if the animals that lacked lesions were animals that had recovered from the diseases and had total resolution of the lesions before slaughter. It is likely that resolution of some lesions occurred. Serious over-estimations of the effects of lesions on growth might occur if concurrent infections and interactions between the lesions are not considered. For example, chronic parietal pleuritis (CPPL) and dorsocaudal pleuritis (CPDC) appeared to be associated with reduced weight gains when the pigs were grouped according to presence or absence of these lesions. However, in regression models for MDG14 and MDG25 and SLAGE, the effects of CPDC and CPPL were either nonsignificant or associated with increased mean daily gains.

The $R^{2}$ values of the regression models ranged from approximately 0.09 to 0.27 . This means that the lesions accounted for only $9-27 \%$ of the variation in mean daily gain and length of the growing period in the 2 herds. The remaining $70-$ $90 \%$ of the variations were due to factors such as environment, feed, genetics, management systems and others that were not studied.

\section{Acknowledgements}

This manuscript is dedicated to Prof. D. V. Sc. Ole Aalund who passed away before completion of the study. The authors thank The Federation of Danısh Pig Producers and Slaughter Houses and The Danish Agricultural and Veterinary Research Councl for the financial support for this project.

\section{References}

Aalund $O$, Willeberg $P$, Mandrup $M$, Riemann $H P$. Lung lesions at slaughter: Associations to factors in the pig herd. Nord. Vet.-Med. 1976, 28, 487-495.

Baalsrud KJ: The effect of atrophic rhinitis on growth rate. Acta vet. scand. 1987, 28, 299-304.

Backstrom L, Hoefling DC, Morkoc AC, et.al.: Effect of Atrophic Rhinitis on Growth Rate in Illinois Swine Herds. J. Amer. Vet. Med. Assoc. 1987, 187, 712-715.

Boessen CR, Kliebenstein JB, Cowart RP, Moore KC,
Burbee CR: Effective use of slaughter checks to determine economic losses from morbidity in swine. Acta vet. scand. 1988, Suppl. 84, 366-368.

Christensen G: Pleuropneumonı hos svin fremkaldt af Haemophilus pleuropneumoniae s. parahaemolytıcus II: Unders $\varnothing$ gelser vedr. epıdemiologi samt relation til kronisk pleuritis (brysthindear) hos slagtesvin. (Pleuropneumonia in swine due to Haemophilus pleuropneumoniae s. parahaemolyticus II. Studies on the epidemiology and the relation to chronic pleuritis (pleural scars) in baconers) Nord. Vet.-Med. 1981, 33, 236-249.

Christensen $G$. Pleuropneumonı hos svin fremkaldt af Haemophilus pleuropneumoniae s. parahaemolytıcus III: Observatıoner vedr. klinısk manifestatıon på besætnıngsplan samt terapeutiske og immunprofylaktiske muligheder. (Pleuropneumonia in swine caused by Haemophilus pleuropneumoniae s. parahaemolyticus III. Studies on the clinical manifestations in herds, treatment and control by vaccination). Nord. Vet.-Med. 1982,34, 113-123.

Christensen G: Brysthındear (kronısk fibrøs pleuritis) hos slagtesvin. (Pleural scars (chronic fibrous pleuritis) in slaughter swine). Dansk Vet. Tidsskr. 1984, 67, 1067-1075.

Chrstensen G: Ondartet lungesyge (pleuropneumoni) hos slagtesvin. Betragtnınger vedrørende sygdommens natur, udbredelse, kødkontrolmssige forhold og dens indflydelse på produktions $\varnothing$ konomi. (Pleuropneumonia in slaughter pigs. Cons1derations on biology, distribution, meat inspection and the impact on economy). Hyologisk Tidsskr. Svinet 1986, 8 (6), 3-8.

Christensen G: USK (Udvidet SygsdomsKontrol)-og den praktiserende dyrlæge. (Extended disease examinations and the practicing veterinarian). Dansk Vet.Tidsskr. 1991, 74, 249-252.

Collins MT, Bckstrom LR, Brim TR: Turbınate per1meter ratio as an indicator of conchal atrophy for diagnosıs of atrophic rhinitıs in pigs. Amer. J. vet. Res. 1989, 150, 421-424.

Cowart RP, Lıpsey, RJ \& Hedrick HB - Measurement of conchal atrophy and pneumonic lesions and their association with growth rate in commingled feeder pigs. J. Amer. vet. med. Ass. 1990, 196, 1262 1264.

Desrosiers $R$, Moore C. A review of some aspects of porcine pleuropneumonia. Proceedings Amer. Ass. Swine Pract., Minneapolis, 1986, 495-511.

Flesj KI, Solberg I: Pathological lesions in swine at slaughter. IV. Pathological lesions in relation to rearıng 
system and herd size. Acta vet. scand. 1981, 22, 272282.

Friendshıp RM, Hacker R, McMıllan I, Pıeper SS, Swaminathan S, Takov R, Wilson MR: Haemophilus Pleuropneumonia: Effect on growth rate and related parameters in naturally occurring disease. Proceedings, Int. Pig Vet. Soc, Ghent, 1984, 97.

KJeldsen N, Nielsen H, Pedersen B: Bestemmelser af slagtesvindets størrelse hos renracede svin og hos krydsningssvin. (Determination of the offal weight in purebred and crossbred slaughter swine). Danske Slagterier internal report. 1990.

Lindqvist JO: Animal health and environment in the production of fattening pigs. A study of disease inc1dence in relation to certain environmental factors, daily weight gain and carcass classification. Acta vet. scand. 1974, suppl.51, 1-78.

Love RJ, Wilson MR, Tasler G: Porcine Atrophic rhinitıs. Aust. vet. J. 1985, 62, 377-378.

Mousing $J$. Brysthındear hos svin: En epidemılogisk beskrivelse af sammenhngen melem vægt, alder og forekomst af brysthindear 1 grise fra 3 konventionelle svinebestninger. (An epidemiologic study of the relationship between weight, age and prevalence of chronic pleuritis in pigs from 3 conventional herds). Dansk Vet.Tidsskr. 1988, 71, 190-197.

Mousing J, Lybye H, Barfod K, Meyling A, Rønsholt $L$, Willeberg $P$. Chronic pleursy in pigs for slaughter- An epidemiological study of infectious and rearing-system related risk factors. Prev. Vet. Med. 1989, 9, 107-119.

Nielsen R, Mandrup M: Pleuropneumonia in swine caused by Haemophllus parahaemolytcus. Nord. Vet.Med. 1977, 29, 465-473.

Noyes EP, Feeny DA, Pljoan C: Comparison of the effect of pneumonia detected during the lifetıme with pneumonia detected at slaughter on growth in swine. J. Amer. vet. med. Assoc. 1990, 197, 10251029.

Paisley LG: A prospective study of the economic impact of chronic pleuritis and other respiratory diseases in two conventional Danish swine herds. Thesss, 1991, Copenhagen, 41-43, 67-70.

Pedersen KB, Barfod $K$ : The aetıological significance of Bordatella bronchiseptica and Pasteurella multocıda in atrophic rhınitıs of swine. Nord. Vet.-Med. 1981, 33, 513-522.

Pointon AM, Byrt D, Heap P: Effect of enzootic pneumonia of pigs on growth performance. Austr. vet. J. 1985, 62, 13-18.
Rasmussen JF: The economic importance of chronic pleurtis in pig production. Proceedings, Int. Pig Vet. Soc , Ghent, 1984, 347.

Ross RF: Chronic pneumonia of swine with emphasis on mycoplasmal pneumonia. Proceedings, Amer. Assoc. Swine Pract. Kansas City, 1984, 79-96.

Sanker SU, Gerbola M-A, Willeberg P, Kirkegaard Petersen B. Patologiske fund ved rutinemæssig og udvidet kødkontrol på slagtesvin. 1. Forekomst og økonomiske konsekvenser for SPF- og konventıonelle besætnınger. (Pathologıcal findings during routıne and extended meat inspections of slaughter swine. 1. Prevalence and economic consequences for SPF and conventional herds). Dansk Vet. Tidsskr. 1982, 65, 550-557.

Sanker SU, Staugaard T: Kassationer af slagtesvin fra SPF/MS-besætninger. (Condemnations of slaughter swine from SPF/MS herds). Dansk Vet.Tidsskr. 1988, 71, 1078-1081.

SAS Institute Inc.: SAS Users Guide: Statistics, Version 5 Edition. Cary, NC: SAS Institute Inc, 1985, 391396.

Saunders JR, Osborne AD, Sebunya JK. Pneumonıa in Saskatchewan swine: Abattoir incidences of intrathoracic lesions in pigs from a herd infected with Haemophilus pleuropneumonia and from other herds. Can. vet. J. 1981, 22, 244-247.

Scheit AB, Mayrose VB, Hill MA, Clark LK, Knox KE, Runnels LJ, Frantz S, Einstein $M E \cdot$ Relationship of growth performance to pneumonia and atrophic rhinitis detected at slaughter. J. Amer. vet. med. Assoc. 1990, 196, 881-884.

Straw BE, Burgı EJ, Hilley HP, Leman AD Pneumonia and atrophic rhinits in pigs from a test station. J. Amer. vet. med. Ass. 1983, 182, 607-611.

Straw BE, Leman AD, Robinson RA: Pneumonia and atrophic rhinitis in pigs from a test station - A Follow-up Study. J. Amer. vet. med. Ass. 1985, 185, 1544-1546.

Straw BE, Tuovinen VK, Bıgras-Poulın M: Estımation of the cost of pneumonia in swine herds. J. Amer. vet. med. Ass. 1989, 195, 1702-1706.

Willeberg P, Gerbola M-A, Sanker SU, Kirkegaard Petersen B: Patologiske fund ved rutınemæssig og udvidet kødkontrol af slagtesvin. 2. Kødkontrollens diagnostıske værdi ved udpegning af mulıge ætiologiske sygdomsenheder, specielt luftvejslidelser. (Pathological findıngs durıng routıne and extended meat inspections of slaughter swine. 2. Diagnostic value of meat inspection findings in determining possible etiologies especially respiratory diseases). Dansk Vet. Tidsskr. 1982, 65, 712-721. 
Willeberg P, Gerbola M-A, Kirkegaard Petersen B, Andersen JB: The Danish pig health scheme: Nationwide computerbased abattoir survellance and follow-up at the herd level. Prev. Vet. Med. 1984/85, 3, 79-91.

Wilson MR, Takov RM, Friendship RM, Martın SW, McMillan I, Hacker R, Swaminathan S: Prevalence of respirato:y diseases and their association with rowth rate and space in randomly selected swine herds. Can. J. vet. Res. 1986, 50, 209-216.

\section{Sammendrag}

En epıdemıologısk og фkonomisk unders $\varnothing$ gelse af luftvejslidelser 12 danske svinebesatninger: Pravalens af luftvejslidelser ved slagtning og disses betydning for tilvokst.

En sammenligning af tilvækstrater for svin med og uden specifikke læsioner ved brug af t-test, og en sammenligning af vækst for svin med forskellige læsıoner ved brug af regressıons modeller påviste, at Mycoplas- ma-lignende pneumoni, kompliceret pneumonia, anterio-ventral pleuritis, fissurer og atrofisk rhınitis nedsatte den gennemsnitlige daglige vækst og forøgede slagtealder i signifikant grad. Den samlede indflydelse af læsioner på gennemsnitlig daglig vækst i perıoden fra 14 dage til slagtning (MDG14) blev estimeret til en reduktion på 27 gram, og læsıonerne medførte endvidere, at perioden blev forlænget med 2 dage 1 besætnıng A. Reduktioner i MDG14 var st $\varnothing$ rre 1 bestning B, nemlig henholdsvis 98 gram og 16,7 dage. Fald i gennemsnitlige daglıge vækstrater 1 perıoden fra fjerde vejnıng til slagtning (MDG25) var 31 gram 1 besætning A og 137 gram i besætning B. Kronısk dorso-kaudal og parietal pleuritıs havde ingen negativ effekt på tilvækstraterne i hverken besætning $\mathrm{A}$ eller $\mathrm{B}$, når der ikke fandtes andre læsioner. Interaktıon imellem læsıoner ændrede ikke estimaterne i betydelig grad. Korrelationskoficienterne fra regressionsmodellerne viser, at forekomst og udbredelse af læsioner ved slagtning kun forklarer $13-27 \%$ af variationerne i tılvækstrater 1 de to besætninger.

(Recelved May 1, 1992; accepted January 10, 1993).

Reprints may be requested from: J. F. Agger, Department of Animal Science and Animal Health, Division of Ethology and Health, Royal Veterınary and Agricultural University, Bülowsvej 13, DK-1870 Frederiksberg C, Denmark. 